ROCZNIKI PEDAGOGICZNE

Tom 12(48), numer $2-2020$

DOI: http://dx.doi.org/10.18290/rped20122-11

IWONA BŁASZCZAK

\author{
ROZWAŻANIA O ZNACZENIU \\ DOSKONALENIA ZAWODOWEGO \\ NAUCZYCIELI EDUKACJI WCZESNOSZKOLNEJ
}

\begin{abstract}
WSTĘP
Rozwój nauki i techniki oraz zmiany społeczno-kulturowe dokonujące się w skali globalnej, regionalnej czy lokalnej sprawiają, że człowiek musi stale się rozwijać, poszerzać swoją wiedzę oraz zdobywać nowe kwalifikacje. W obliczu zmieniającego się życia i warunków pracy niezbędne jest dostosowanie się do tych zmian przez odpowiednią edukację, wykształcenie i doskonalenie swoich umiejętności. W nowocześnie zarządzanych instytucjach stawia się na rozwój i samodzielność pracowników. Również nauczyciele są zmuszeni przez cały czas podnosić swoje kwalifikacje, zdobywać nowe doświadczenie, pogłębiać wiedzę. Dynamika zmian w otoczeniu człowieka sprzyja konieczności uczenia się przez całe życie. Edukacja ustawiczna nauczycieli jest więc koniecznością, pomaga ona w zrozumieniu nowych problemów i zjawisk wychowawczych, życia codziennego i potrzeb wychowanków.

W niniejszym artykule omówiony zostanie fragment pilotażowych badań empirycznych, rozpoczętych przez autorkę w 2018 r. na losowo wybranej grupie nauczycieli edukacji wczesnoszkolnej ze szkół warszawskich. Badania te zostaną powtórzone na ogólnopolskiej grupie respondentów. Autorka sformułowała hipotezę, że podnoszenie kwalifikacji zawodowych przez nauczycieli edukacji wczesnoszkolnej wpływa pozytywnie na ich postawy zawodowe i tym samym może zwiększać ich zaangażowanie oraz satysfakcję z wykonywanej pracy.
\end{abstract}

Dr Iwona BŁASzCZAK - Instytut Nauk Socjologicznych i Pedagogiki; Wydział Socjologii i Pedagogiki Uniwersytet Przyrodniczy, Szkoła Główna Gospodarstwa Wiejskiego w Warszawie; e-mail: iwona_blaszczak@sggw.edu.pl; ORCID: https://orcid.org/0000-0002-3015-6837. 
Znawcy problematyki - Dzierżymir Jankowski, Kazimierz Przyszczypkowski i Józefa Skrzypczak - definiują edukację dorosłych jako proces zewnętrznego oddziaływania na rozwijającą się jednostkę, celem jej ukształtowania zgodnie ze społecznie wyobrażonym jej dobrem indywidualnym oraz interesem społeczeństwa czy jego określonych struktur (wspólnot, grup celowych, instytucji), których jest ona członkiem. Celem tak rozumianego wychowania staje się umożliwienie jednostce lepszego funkcjonowania w poszczególnych rolach społecznych, służące indywidualnemu awansowi (Jankowski i in., 1996, s. 13-14). Jak podkreśla Zygmunt Wiatrowski (2005, s. 365): „Kształcenie ustawiczne dorosłych to proces systematycznego uczenia się, następujący po zakończeniu obowiązku szkolnego lub wydłużonej edukacji stacjonarnej i trwający przez cały okres aktywności zawodowej, a często także dłużej”.

Ponieważ kształcenie dzieci i młodzieży jest czymś naturalnym i zrozumiałym dla wszystkich, ideę całożyciowego kształcenia się, a zwłaszcza jego konieczności, zaczęto odnosić do edukacji dorosłych, wiążąc ją także ze szkoleniem, dokształcaniem i doskonaleniem zawodowym (Suchy, 2010, s. 86).

W kontekście tych przemyśleń kształcenie ustawiczne nauczycieli edukacji wczesnoszkolnej stanowi podstawę efektywnej realizacji ich zadań dydaktyczno-wychowawczych. Ma ono ścisły związek przede wszystkim z globalnym dostępem do informacji i wiedzy bez względu na czas i przestrzeń.

EDUKACJA USTAWICZNA - ISTOTA I ZADANIA

Edukacja służy ochronie i ulepszaniu naturalnego środowiska człowieka, by przez to sprzyjać jego wszechstronnemu rozwojowi. Zadaniem edukacji dorosłych jest ukierunkowanie i wdrażanie uczestników do samokształcenia, rozwijania postaw i wzbogacenia poziomu moralnego (Suchy, 2010, s. 86).

Raport Międzynarodowej Komisji do Spraw Rozwoju Edukacji przygotowany pod kierunkiem E. Faure'a ujmuje istotę i zadania edukacji dorosłych w następujący sposób:

$>$,zastępuje ona kształcenie początkowe dla bardzo dużej części ludzi dorosłych na świecie,

> uzupełnia kształcenie początkowe lub zawodowe wielu ludzi, którzy nie otrzymali dostatecznego wykształcenia,

$>$ przedłuża kształcenie i pomaga ludności w sprostaniu nowym wymaganiom stawianym przez środowisko, 
doskonali wiedzę i umiejętności tych, którzy osiągnęli stosunkowo wysoki poziom wykształcenia,

$>$ otwiera przed wszystkimi ludźmi drogę indywidualnego rozwoju.

W poszczególnych krajach jeden $\mathrm{z}$ tych aspektów może być ważniejszy niż inne, ale wszystkie mają wszędzie swoje istotne znaczenie" (tamże, s. 87).

Współcześnie w kwestii praktyki i teorii kształcenia całożyciowego wyrażane są różne stanowiska, różne klasyfikacje i określenia oraz różne interpretacje. Przyjęto, że najogólniejszym terminem, który uzyskał powszechne uznanie jest termin edukacja permanentna. Przez edukację permanentną rozumie się najczęściej ogół procesów oświatowo-wychowawczych, występujących w całym okresie życia człowieka, a zatem procesów całożyciowych, prowadzonych we wszelkich możliwych formach organizacyjno-programowych i we wszystkich sytuacjach kontaktów międzyludzkich (Wiatrowski, 2005, s. 365).

Czym więc jest edukacja dorosłych? Można z całą pewnością stwierdzić, że jest czynnym udziałem w modyfikowaniu warunków rozwoju psychofizycznego dorosłych, wspomaganiem tego rozwoju poprzez wyzwalanie własnych sił rozwojowych jednostki, pokazywanie nie zawsze uświadomionych przez człowieka jego własnych możliwości, rozwijanie w bezpośrednim środowisku warunków wielostronnej, korzystnej aktywności edukacyjnej, a w przypadku patologicznych stanów psychologicznych i psychicznych żmudnym odbudowywaniem poprzez resocjalizację i psychoterapię zdolności normalnego zaspokajania wszystkich podstawowych potrzeb ludzkich oraz prawidłowego funkcjonowania w społeczeństwie.

Kształcenie ustawiczne traktuje się więc $\mathrm{z}$ jednej strony jako instrument podniesienia poziomu wiedzy i umiejętności dostosowania się do zmieniających się warunków, a z drugiej jako sposób podnoszenia uczestnictwa i aktywności obywateli w życiu społecznym, politycznym i kulturalnym. Jeszcze do niedawna stosunkowo mało uwagi, zarówno w teorii, jak i w badaniach, poświęcano uczeniu się dorosłych, pomimo faktu, że kształcenie dorosłych interesowało uczonych od wieków. Już w starożytności Konfucjusz, Lao Tse w Chinach, prorocy hebrajscy, Arystoteles, Sokrates czy Platon byli nauczycielami dorosłych. Postrzegali oni uczenie się nie tylko jako bierny odbiór przekazywanych treści, ale przede wszystkim jako proces dociekań umysłowych (Knowles, Holton 2009, s. 42). Jednakże pomimo zainteresowania problemem kształcenia dorosłych, zarówno w Stanach Zjednoczonych, jak i w Europie, dopiero po zakończeniu II wojny światowej zaczęto więcej uwagi poświęcać temu, jakie specyficzne właściwości posiadają 
dorośli uczniowie. W 1926 r. pojawił się nurt artystyczny, który dążył do odkrycia nowej wiedzy poprzez intuicję i analizę doświadczeń. W nurcie tym interesowano się, w jaki sposób uczą się dorośli. Początek tym badaniom dała publikacja E.C. Lindemana The meaning of adulteducation, który dał podwaliny pod usystematyzowaną teorię uczenia się dorosłych. W swoich wnikliwych stwierdzeniach Lindeman ujął m.in. następujące poglądy:

$>$ „Najważniejsza wartość dla edukacji dorosłych to doświadczenie osoby uczącej się.

Każdy dorosły człowiek, który znajduje się w określonych sytuacjach mających związek z jego pracą, życiem rodzinnym, czasem wolnym, które wymagają dostosowania się, pozostający w ramach danej zbiorowości rozpoczyna w tym miejscu swoją edukację dorosłego.

$>$ Teksty i nauczyciele odgrywają drugorzędną rolę, ustępując miejsca uczącym się.

$>\mathrm{W}$ edukacji dorosłych nie ma miejsca na egzaminy i autorytarny sposób nauczania oraz na sztywne reguły pedagogiczne.

Edukacja dorosłych jest to proces, dzięki któremu uczniowie stają się świadomi, jaką wagę mają ich doświadczenia.

Celem nadrzędnym edukacji dorosłych jest odkrywanie znaczenia doświadczeń" (tamże, s. 44).

\section{CELE I ZADANIA}

\section{PODNOSZENIA KWALIFIKACJI ZAWODOWYCH NAUCZYCIELI}

$\mathrm{Na}$ kompetencje zawodowe składa się wiele elementów, m.in.: umiejętności, wiedza czy predyspozycje psychologiczno-społeczne. Nie są to cechy stałe. Wraz z poznawaniem nowych treści, nabywaniem doświadczenia ulegają one zmianom i dezaktualizacji. Wszystkie elementy kwalifikacji wymagają ciągłego doskonalenia, co daje korzyści zarówno nauczycielowi, jak i uczniom, z którymi pracuje.

Obowiązek organizowania i prowadzenia dokształcania i doskonalenia kwalifikacji zawodowych przez zakład pracy wynika z postanowień kodeksu pracy. Zgodnie z wydanymi na podstawie Kodeksu Pracy przepisami regulującymi zagadnienia podnoszenia kwalifikacji zawodowych pracowników w zakładzie pracy dokształcanie pracowników rozumiane jest jako uzyskiwanie wyższego poziomu wykształcenia i odbywa się w systemie szkolnym na podstawie skierowania zakładu pracy (szkoły wieczorowe lub zaoczne) 
i jego celem jest na ogół uzyskanie przez pracownika poziomu wykształcenia wymaganego na zajmowanym przez niego stanowisku. Natomiast doskonalenie kwalifikacji pracowników rozumiane jest jako stały proces aktualizacji i modernizacji wiedzy i umiejętności zawodowych w celu dostosowania ich do zmieniających się wymagań i zadań na zajmowanych stanowiskach pracy, w miarę postępu techniki i technologii produkcji (Osmelak, 1999, s. 121).

Sprawne funkcjonowanie szkoły zależy w pierwszej kolejności od samych nauczycieli, którzy są w niej zatrudnieni i stanowią jej kapitał ludzki. Dzieje się tak, ponieważ wszystkie czynniki determinujące w sposób całościowy sprawne funkcjonowanie organizacji, jaką jest szkoła, ich sposób zdobywania i wykorzystania zależą od ludzi w niej zatrudnionych. Nauczyciele są szczególnym ,zasobem” szkoły. To ich kompetencje w postaci wiedzy, doświadczenia, umiejętności i zdolności stają się kapitałem o charakterze strategicznym, który pozwala zdobywać przewagę konkurencyjną (Król, Ludwiczyński, 2007, s. 11). Dlatego warto inwestować w rozwój zawodowy nauczycieli, ponieważ prowadzi to do osiągania korzyści w postaci lepszego bytu, możliwości dalszego rozwoju, satysfakcji z wykonywanej pracy i podniesienia jakości życia.

Celem rozwoju kwalifikacji i kompetencji zawodowych nauczycieli jest uzyskanie przez placówkę edukacyjną na tyle wykwalifikowanych pracowników, żeby ich zatrudnienie gwarantowało osiąganie celów organizacji efektywność, skuteczność, wydajność. Poprzez rozwój nowych kompetencji i kwalifikacji nauczycieli zapewnia się funkcjonowanie szkoły, kreatywność i innowacyjność, które są motorem rozwoju każdej instytucji.

Rozwój zawodowy pracowników (nauczycieli) obejmuje następujące elementy:

> Naukę - ciągłą zmianę zachowania na skutek praktyki lub doświadczenia.

Edukację - poszerzenie wiedzy, rozwój wartości i zdolności pojmowania wymagań we wszystkich sferach życia, a nie tylko wiedzy i umiejętności związanych z dziedzinami lub czynnościami, z którymi wiąże się praca danej osoby.

Rozwój - realizowanie możliwości i potencjału pracowników poprzez doświadczenia związane z nauką i edukacją.

Szkolenie - planowane i systematyczne zmiany zachowania na skutek pojedynczych wydarzeń, programów i instrukcji, które umożliwiają zdobycie wiedzy, umiejętności i kompetencji potrzebnych do właściwej realizacji zadań (Armstrong, 2000, s. 425-426). 


\section{ROLA SZKOLEŃ W ROZWOJU KWALIFIKACJI \\ I KOMPETENCJI ZAWODOWYCH NAUCZYCIELI}

Według Aleksego Pocztowskiego (2008, s. 221), głównym celem szkolenia jest ciągły rozwój poszczególnych elementów potencjału pracy indywidualnych pracowników lub ściśle określonych grup, celem dostosowania ich do zachodzących i antycypowanych zmian w organizacji i otoczeniu.

Szkolenia, a tym samym podnoszenie kwalifikacji nauczycieli nie mogą mieć charakteru przypadkowego, incydentalnego, uwzględniającego tylko pewne doraźne potrzeby niektórych osób. Aby szkolenie nauczycieli przyniosło spodziewane rezultaty, musi być ono działaniem planowym i długookresowym. Realizację głównego celu szkolenia, jakim jest podniesienie kwalifikacji nauczycieli, można rozpatrywać zarówno z punktu widzenia szkoły, jak i nauczyciela.

Duże znaczenie odgrywają tu specjalistyczne szkolenia - odpowiednio dobrane szkolenia zwiększają konkurencyjność nauczycieli na rynku pracy, m.in. poprzez podniesienie efektywności działania. Poniżej przedstawiono korzyści, jakie wynikają z uczestnictwa w szkoleniach, zarówno dla samych pracowników, jak i pracodawców.

Tabela 1. Korzyści z prowadzonych szkoleń

\begin{tabular}{|l|l|}
\hline \multicolumn{2}{|c|}{ KORZYŚCI } \\
\hline \multicolumn{1}{|c|}{ Dla pracodawcy } & \multicolumn{1}{|c|}{ Dla pracownika } \\
\hline - Podniesienie efektywności. & \multicolumn{1}{|c|}{ - Zwiększenie standardu wykonywanej pracy. } \\
- Szybsza adaptacja nowych technik & - Poszerzenie wiedzy. \\
i technologii. & Udoskonalenie umiejętności. \\
- Zwiększenie elastyczności w gospodarowaniu & - Zaspokojenie potrzeby samorealizacji. \\
zasobami ludzkimi. & - Wzrost zarobków. \\
- Rozwój potencjału ludzkiego. & Pomoc w realizowaniu ścieżki własnej \\
- Zwiększenie konkurencyjności. & kariery, awans. \\
- Dobra opinia o firmie jako dbającej o swoich & \\
pracowników. & \\
- Zmotywowani, zaangażowani pracownicy. & \\
- Mniejsza fluktuacja pracowników. \\
- Pracownicy zintegrowani z firmą. \\
- Lepsza komunikacja wewnątrz firmy.
\end{tabular}

Źródło: Janowska, 2001, s. 139. 
Dobrze przygotowane szkolenia przeznaczone dla nauczycieli mogą:

$>$ Zapobiec popełnieniu ewentualnych błędów dydaktyczno-wychowawczych.

Poprawić efekty pracy dydaktyczno-wychowawczej osiągane przez nauczycieli, zespół i szkołę, czyli: rezultaty, jakość, tempo i skuteczność działań dydaktyczno-wychowawczych.

$>$ Zwiększyć elastyczność operacyjną poprzez rozszerzenie zakresu konkretnych umiejętności nauczycieli, jak np.: radzenie sobie w sytuacjach konfliktowych.

Zwiększyć zaangażowanie nauczycieli, zachęcając ich do utożsamiania się z misją i celami szkoły.

Pomóc w zarządzaniu zmianą, pozwalając zrozumieć przyczynę tej zmiany i zapewniając nauczycielom wiedzę i umiejętności, jakich potrzebują, aby przystosować się do nowych sytuacji.

Pomóc w stworzeniu w szkole pozytywnej atmosfery, np. zorientowanej na osiąganie lepszych celów.

Poprawić poziom usług.

Aby szkolenie skierowane do nauczycieli spełniło oczekiwane efekty, należy uświadomić uczestnikom, że konieczna jest ich refleksja nad tym, czy dobrze sobie radzą w swoich codziennych zadaniach. Można ją pobudzić poprzez np. zadawanie pytań, pod warunkiem jednak, że pytania będą przemyślane, nienachalne i niewywierające presji. Większość ludzi niechętnie stawia czoło zmianom, które przychodzą wraz ze szkoleniami. Dlatego też działania szkoleniowe należy połączyć z odpowiednimi technikami motywacyjnymi. Dyrektorzy powinni także pomyśleć o kontrolowanym delegowaniu uprawnień, odpowiedzialności. Wyrażają w ten sposób dbałość o to, by nauczyciele nie tylko wiedzieli, czego się od nich oczekuje, ale aby rozumieli, co muszą wiedzieć i co muszą umieć, aby wykonać powierzone im zadania w zadowalający sposób. Dzięki tym informacjom mogą udzielić instrukcji już na samym wstępie. W późniejszym etapie udzielanie instruktażu może być odbierane jako wtrącanie się. Promocja kształcenia, samokształcenia, motywacja i umiarkowany nadzór stanowią gwarancję pozytywnego nastawienia nauczycieli do szkoleń i rozwoju.

Duże znaczenie ma również wybór techniki szkoleniowej. To od niej zależy, na ile skuteczne będzie szkolenie, szybkość wprowadzenia innowacji, powodzenie projektów i efektywność pracy nauczycieli. Wśród technik szkoleniowych możemy wyróżnić: 
„Techniki szkolenia na stanowisku pracy - coaching, demonstracje, mentoring, planowe nabywanie doświadczenia, rotacja stanowisk pracy.

Techniki szkolenia poza stanowiskiem pracy stosowane podczas formalnych kursów szkoleniowych poza miejscem pracy - wykłady, dyskusje, rozmowy, studium przypadku, metody odkrywcze, symulacje, ćwiczenia grupowe, odgrywanie ról, budowanie zespołów, szkolenia zewnętrzne, uczenie się na odległość, warsztaty.

Techniki szkolenia na stanowisku pracy lub poza nim - pytania i odpowiedzi, instrukcje, zadania, uczenie się poprzez działanie, projekty, czytanie pod kierunkiem, zadania, szkolenie wspomagane komputerowo, wideo i wideo interaktywne" (Armstrong, 2000, s. 460).

Niezależnie od charakteru szkolenia ważne jest, aby każde przygotowywało nauczycieli na nieustanne zmiany otoczenia, angażowało w wypracowywanie nowych, skutecznych rozwiązań i przekonywało ich, że zmiana przyniesie korzyści wszystkim - szkole, uczniom i nauczycielom (Szkutnicki, 2001, s. 6). Dla wielu dyrektorów szkół dbanie o rozwój intelektualny i zawodowy nauczycieli uzyskało status zadania strategicznego. Kształcenie i rozwój pracowników sprzyja poszerzaniu ich horyzontów, zdobywaniu nowych kompetencji i kwalifikacji, rozwijaniu cech osobowości, takich jak przedsiębiorczość, innowacyjność, a także zaspokajaniu potrzeby samorealizacji samych szkolonych.

Możliwość rozwoju zawodowego nauczycieli jest jedną z podstawowych wartości w życiu zawodowym. Nieadekwatne działania rozwojowe mogą rodzić poczucie frustracji i prowadzić do odejścia ze szkoły wartościowych nauczycieli, którzy być może w innej pracy dostrzegą możliwości wykorzystania własnych kompetencji. Rozwój zawodowy wymaga odpowiedniego, długofalowego zarządzania. Nauczyciel usatysfakcjonowany, zadowolony, doceniony to dobry i wydajny pracownik.

\section{POZASZKOLNE FORMY DOSKONALENIA ZAWODOWEGO}

Obecnie na rynku istnieje bogata oferta różnych pozaszkolnych form doskonalenia kwalifikacji zawodowych.

Pozaszkolnymi formami doskonalenia zawodowego są:

$>$ „kursy, seminaria kursokonferencyjne,

$>$ staże zawodowe i praktyki pracownicze,

$>$ samokształcenie kierowane, 
szkolenie, instruktaż" (Griffin, 2010, s. 49).

Podstawową formą pozaszkolnego doskonalenia kwalifikacji pracowników jest kurs. Ze względu na cel dydaktyczny kursy można podzielić na:

1) doskonalące kwalifikacje,

2) przygotowujące do egzaminów eksternistycznych,

3) nauki języka obcego.

Natomiast ze względu na organizację zajęć dydaktycznych rozróżniamy kursy:

1) stacjonarne, $\mathrm{z}$ całkowitym lub częściowym oderwaniem od pracy oraz bez oderwania od pracy (wewnątrzzakładowe),

2) zaoczne (korespondencyjne), polegające na samodzielnym przyswajaniu wiedzy przez uczestników kursu przy pomocy materiałów szkoleniowych, przewodników metodycznych i instrukcji dostarczanych przez organizatorów oraz na udziale uczestników w obowiązkowych zajęciach konsultacyjnych.

Bardziej popularną i krótszą formą doskonalenia zawodowego jest seminarium, w którego programie przeważają zajęcia aktywizujące i wykłady monograficzne, prowadzone metodą konwersatoryjno-dyskusyjną.

Odmianą kursu jest kursokonferencja. Jest to forma szczególnie rozpowszechniona w doskonaleniu kadr kierowniczych. Kursokonferencja to zamknięty cykl zajęć dydaktycznych o określonej tematyce, którego łączny czas trwania nie powinien przekraczać trzech dni.

Ważne miejsce w procesie podnoszenia kwalifikacji pracowników powinny zajmować staże pracownicze, organizowane przez instytucje edukacyjne wiodące prym w danej dziedzinie. Programy staży zawodowych powinny być ustalane oddzielnie dla poszczególnych pracowników lub ich grup. Mniej powszechną, ale mającą obecnie coraz większe znaczenie formą doskonalenia kwalifikacji kadr jest samokształcenie kierowane. Jego zaletą jest to, że pozwala doskonalić kwalifikacje pracowników i planować ich wszechstronny rozwój zawodowy bez konieczności odrywania od warsztatu pracy.

Samokształcenie kierowane jako nowoczesna i funkcjonalna forma doskonalenia zawodowego umożliwia:

,,jednoczesne objęcie doskonaleniem dowolnej liczby pracowników,

ścisłe powiązanie treści i zakresu doskonalenia kwalifikacji zawodowych pracowników z potrzebami kadrowymi zakładu pracy,

$>$ lepsze dostosowanie zakresu i stopnia trudności treści doskonalenia zawodowego do możliwości percepcyjnych danej grupy czy kategorii zawodowej pracowników,

$>$ nieodrywanie pracownika od warsztatu pracy zawodowej, 
ścisłe powiązanie rozwoju zawodowego pracownika z jego awansem zawodowym, a więc pełny i wszechstronny rozwój społeczno-zawodowy" (McKenna, Beech, 1999, s. 152).

Andragodzy w swoich badaniach postrzegają człowieka dorosłego jako podmiot, który dzięki temu, że oddziałuje wychowawczo i uprawia samowychowanie, ma możliwość samodzielnej realizacji w różnych dziedzinach życia. Ujmują samowychowanie dorosłego ściśle $\mathrm{z}$ jego samopoznaniem i pełnionymi przez niego rolami społecznymi, zwracając szczególną uwagę na modyfikację scenariuszy przez ludzi i na to, że każdy dopasowuje je do swojej indywidualności (Turos, 2004, s. 11).

\section{WYBRANE WYNIKI BADAŃ}

Dla potrzeb niniejszego artykułu przeprowadzono sondaż diagnostyczny przy użyciu kwestionariusza ankiety. W badaniu udział wzięła losowo wybrana, 100-osobowa grupa nauczycieli edukacji wczesnoszkolnej. Wszyscy respondenci zadeklarowali, że $\mathrm{w}$ trakcie pracy zawodowej uczestniczyli w różnych szkoleniach lub programach podnoszenia kwalifikacji zawodowych. Badanie było anonimowe. Kwestionariusz składał się z 23 pytań, w tym pytania od 1 do 18 były pytaniami zamkniętymi, jednokrotnego wyboru, a od 20 do 23 - pytaniami metryczkowymi. Każde z pytań pozwalało badanym na udzielenie jednej z 5 odpowiedzi i przypisanie im wybranej skali ocen. Pytanie nr 19 miało charakter pytania otwartego z tym, że ankietowanym dano możliwość zaznaczenia 2 z 8 opcji do wyboru.

Badanie zostało przeprowadzone w okresie od 12 kwietnia do 14 czerwca 2018 r. Wyniki wszystkich wypełnionych ankiet (w formie elektronicznej oraz na wydrukach) zostały przeniesione do arkusza MS Excel, gdzie poddane zostały analizie i późniejszej interpretacji. Wśród respondentów przeważały kobiety zatrudnione mniej niż 12 lat.

Tabela nr 2. Syntetyczne wyniki i odpowiedzi na pytania badawcze

\begin{tabular}{|c|c|c|c|c|c|c|c|c|c|c|c|}
\hline \multirow{2}{*}{ Lp. } & \multirow{2}{*}{ Pytanie } & \multicolumn{4}{|c|}{ Oceny } & \multicolumn{6}{|c|}{ Liczba ocen } \\
\hline & & Śr & $\mathrm{Me}$ & Min & Max & 1 & 2 & 3 & 4 & 5 & Razem \\
\hline 1. & $\begin{array}{l}\text { Czy Pani/Pana zdaniem rozwój } \\
\text { motywuje? }\end{array}$ & 4,57 & 5 & 1 & 5 & 2 & 0 & 0 & 35 & 63 & 100 \\
\hline 2. & $\begin{array}{l}\text { Czy uważa Pani/Pan, że podnoszenie } \\
\text { kwalifikacji pracowników poprzez różne }\end{array}$ & 4,69 & 5 & 2 & 5 & 0 & 3 & 1 & 20 & 76 & 100 \\
\hline
\end{tabular}




\begin{tabular}{|c|c|c|c|c|c|c|c|c|c|c|c|}
\hline \multirow{2}{*}{ Lp. } & \multirow{2}{*}{ Pytanie } & \multicolumn{4}{|c|}{ Oceny } & \multicolumn{6}{|c|}{ Liczba ocen } \\
\hline & & Śr & $\mathrm{Me}$ & Min & $\operatorname{Max}$ & 1 & 2 & 3 & 4 & 5 & Razem \\
\hline & $\begin{array}{l}\text { formy (szkolenia, kursy, studia) jest } \\
\text { potrzebne? }\end{array}$ & & & & & & & & & & \\
\hline 3. & $\begin{array}{l}\text { Czy czuje Pani/Pan potrzebę } \\
\text { podnoszenia kwalifikacji i uczestnictwa } \\
\text { w szkoleniach? }\end{array}$ & 4,55 & 5 & 1 & 5 & 2 & 1 & 2 & 30 & 65 & 100 \\
\hline 4. & $\begin{array}{l}\text { Czy według Pani/Pana podnoszenie } \\
\text { kwalifikacji powinno stanowić stały } \\
\text { element uzupełniania i zdobywania } \\
\text { wiedzy i umiejętności w firmie? }\end{array}$ & 4,71 & 5 & 1 & 5 & 2 & 0 & 3 & 15 & 80 & 100 \\
\hline 5. & $\begin{array}{l}\text { Czy Pani/Pana zdaniem podnoszenie } \\
\text { kwalifikacji wpływa na rozwój } \\
\text { pracowników? }\end{array}$ & 4,64 & 5 & 1 & 5 & 2 & 0 & 1 & 26 & 71 & 100 \\
\hline 6. & $\begin{array}{l}\text { Czy wykorzystuje Pani/Pan w swojej pracy } \\
\text { uzyskaną podczas szkoleń wiedzę } \\
\text { i umiejętności? }\end{array}$ & 4,42 & 5 & 1 & 5 & 1 & 2 & 5 & 38 & 54 & 100 \\
\hline 7. & $\begin{array}{l}\text { Czy Pani/Pana zdaniem możliwość } \\
\text { podnoszenia kwalifikacji i udziału } \\
\text { w szkoleniach pracowniczych może mieć } \\
\text { motywujące działanie na pracownika? }\end{array}$ & 4,44 & 5 & 2 & 5 & 0 & 2 & 7 & 36 & 55 & 100 \\
\hline 8. & $\begin{array}{l}\text { Czy w Pani/Pana firmie pracownicy mają } \\
\text { możliwości podnoszenia kwalifikacji } \\
\text { poprzez kursy, szkolenia, studia w celu } \\
\text { zwiększenia swoich kompetencji? }\end{array}$ & 4,26 & 5 & 1 & 5 & 2 & 7 & 5 & 35 & 51 & 100 \\
\hline 9. & $\begin{array}{l}\text { Jeśli podnosiła Pani/Pan swoje kwalifikacje } \\
\text { zawodowe, to czy w Pani/Pana opinii } \\
\text { ukończone szkolenia, kursy, studia } \\
\text { przyczyniły się do zwiększenia Pani/Pana } \\
\text { motywacji do dalszego rozwoju } \\
\text { zawodowego? }\end{array}$ & 3,66 & 4 & 1 & 5 & 6 & 17 & 6 & 47 & 24 & 100 \\
\hline 10. & $\begin{array}{l}\text { Czy podniesienie kwalifikacji zawodowych } \\
\text { spowodowało wzrost Pani/Pana motywacji } \\
\text { do lepszego wykonywania obowiązków } \\
\text { zawodowych? }\end{array}$ & 4,15 & 4 & 2 & 5 & 0 & 5 & 9 & 52 & 34 & 100 \\
\hline 11. & $\begin{array}{l}\text { Czy podniesienie kwalifikacji zawodowych } \\
\text { przyczyniło się do wzrostu Pani/Pana } \\
\text { samooceny? }\end{array}$ & 3,90 & 4 & 2 & 5 & 0 & 9 & 18 & 47 & 26 & 100 \\
\hline 12. & $\begin{array}{l}\text { Czy podniesienie kwalifikacji zawodowych } \\
\text { zwiększyło Pani/Pana zaangażowanie } \\
\text { w realizację zadań służbowych? }\end{array}$ & 4,09 & 5 & 1 & 5 & 3 & 10 & 13 & 23 & 51 & 100 \\
\hline 13. & $\begin{array}{l}\text { Czy podniesienie kwalifikacji zawodowych } \\
\text { zwiększyło Pani/Pana kreatywność } \\
\text { w wykonywaniu zadań? }\end{array}$ & 3,94 & 4 & 1 & 5 & 1 & 12 & 9 & 48 & 30 & 100 \\
\hline
\end{tabular}




\begin{tabular}{|c|c|c|c|c|c|c|c|c|c|c|c|}
\hline \multirow{2}{*}{ Lp. } & \multirow{2}{*}{ Pytanie } & \multicolumn{4}{|c|}{ Oceny } & \multicolumn{6}{|c|}{ Liczba ocen } \\
\hline & & Śr & Me & Min & Max & 1 & 2 & 3 & 4 & 5 & Razem \\
\hline 14. & $\begin{array}{l}\text { Czy Pani/Pana zdaniem podnoszenie } \\
\text { kwalifikacji zawodowych poprzez udział } \\
\text { w różnych formach szkoleniowych } \\
\text { organizowanych przez Pani/Pana firmę ma } \\
\text { wpływ na rozwój kariery zawodowej? }\end{array}$ & 3,68 & 4 & 1 & 5 & 4 & 20 & 9 & 38 & 29 & 100 \\
\hline 15. & $\begin{array}{l}\text { Czy chętnie podnosi Pani/Pan swoje } \\
\text { kwalifikacje zawodowe w organizowanych } \\
\text { przez pracodawcę formach szkoleniowych? }\end{array}$ & 4,31 & 4 & 1 & 5 & 1 & 2 & 7 & 45 & 45 & 100 \\
\hline 16. & $\begin{array}{l}\text { Czy prowadzone formy szkoleniowe } \\
\text { spełniają Pani/Pana oczekiwania? }\end{array}$ & 4,20 & 4 & 1 & 5 & 1 & 5 & 13 & 35 & 46 & 100 \\
\hline 17. & $\begin{array}{l}\text { Czy w codziennych obowiązkach } \\
\text { wykorzystuje Pani/Pan wiedzę zdobytą } \\
\text { podczas podnoszenia kwalifikacji? }\end{array}$ & 3,76 & 4 & 1 & 5 & 6 & 1 & 14 & 69 & 10 & 100 \\
\hline 18. & $\begin{array}{l}\text { Czy Pani/Pana zdaniem podnoszenie } \\
\text { kwalifikacji wpływa pozytywnie na } \\
\text { pracowników i ich satysfakcję z pracy? }\end{array}$ & 4,24 & 4 & 1 & 5 & 1 & 5 & 8 & 41 & 45 & 100 \\
\hline & Razem & 4,23 & 4 & 1 & 5 & 34 & 101 & 130 & 680 & 855 & 1800 \\
\hline
\end{tabular}

Źródło: opracowanie własne

W odpowiedziach na pytanie badawcze ankietowani wykorzystali wszystkie stopnie ocen. Widoczna jest wyraźna przewaga ocen pozytywnych, oceny neutralne i negatywne stanowią zaledwie $14,72 \%$.

Mediana ocen indywidualnych wynosi 4 , zatem ponad $50 \%$ wszystkich ocen w ankietach jest wyższa od 4. Średnie oceny dla większości pytań są pozytywne (wynik większy lub równy 4), brak jest negatywnych, tylko dla 5 pytań oceny są względnie pozytywne (przedział od 3 do 4). Ankietowani $\mathrm{z}$ umiarkowanym optymizmem potwierdzają (pytania 9, 11, 13, 14, 17), że podnoszenie kwalifikacji zawodowych poprzez szkolenia przyczynia się do zwiększenia motywacji do dalszego rozwoju zawodowego, do wzrostu samooceny, zwiększa kreatywność w wykonywaniu zadań, ma wpływ na rozwój kariery zawodowej, a zdobyta wiedza możliwa jest do wykorzystania w codziennych obowiązkach. Jednocześnie ankietowani wyraźnie potwierdzają, że szkolenia są potrzebne, przydatne i chętnie w nich uczestniczą. Średnia ocena (wynik) dla wszystkich pytań i wypełnionych ankiet wynosi 4,23.

Rozkład średnich wyników 100 ankiet świadczy, że średnie oceny, oceniane jako negatywne, uzyskane zostały w 2 ankietach. Ocena względnie negatywna uzyskana została w 1 ankiecie. Oceny względnie pozytywne wystąpiły w 23 ankietach. W pozostałych 74 ankietach oceny są pozytywne, przy 
czym w 2 ankietach wszystkie pytania otrzymały maksymalną ocenę. Wykres średnich wskazuje na asymetrię lewostronną rozkładu wyników. Ankietowani wskazali również na najsilniejszy wpływ podnoszenia kwalifikacji w odniesieniu do zwiększenia efektywności oraz wzrostu motywacji. Najsłabszy związek wskazany został w obszarach korzyści materialnych (awans, wzrost wynagrodzenia).

Reasumując udzielone przez ankietowanych odpowiedzi: pytania dotyczące szkoleń jako takich, ich przydatności oraz celowości ocenione zostały wyżej niż pytania dotyczące faktycznego wpływu, jaki odbyte szkolenia mają na ankietowanych. Ankietowani są przekonani, że generalnie podnoszenie kwalifikacji zawodowych poprzez szkolenia wpływa na rozwój ich pozytywnych postaw i satysfakcji z pracy, chociaż w aspekcie materialnym wpływ ten nie jest tak wyraźny, jak by tego oczekiwali. Awans zawodowy i wynikające $\mathrm{z}$ tego korzyści materialne są niezaprzeczalną formą kreowania pozytywnych postaw i satysfakcji z pracy. Ankietowani potwierdzają, aczkolwiek niestanowczo, że podnoszenie kwalifikacji pomaga im w rozwoju na ścieżce kariery. Szkolenia, jako forma podnoszenia kwalifikacji i sam udział w nich, są oceniane bardzo pozytywnie.

Średni wynik ankiety jest większy od 4 , co zgodnie z przyjętą metodą stanowi potwierdzenie hipotezy badawczej, czyli podnoszenie kwalifikacji zawodowych ma pozytywny wpływ na postawy nauczycieli przez co wzrasta ich zaangażowanie i satysfakcja z pracy. Dodatkowym potwierdzeniem hipotezy jest lewostronna asymetria rozkładu wyników ankiet i odpowiedzi na pytania badawcze oraz wyraźnie zaznaczona dominanta w przedziale średnich ocen w ankietach od 4 do 4,5.

\section{PODSUMOWANIE}

Szkolenie i rozwój nauczycieli edukacji wczesnoszkolnej i przedszkolnej poprzez umożliwienie im podnoszenia kwalifikacji zawodowych to elementy właściwego zarządzania szkołą, mające na celu uzupełnienie wiedzy oraz doskonalenie umiejętności i kompetencji niezbędnych do prawidłowego wykonywania zadań na danym stanowisku pracy. To również element kształcenia ustawicznego, tak ważnego w życiu każdego człowieka. Sprzyjają one poszerzaniu horyzontów poznawczych nauczycieli oraz ich przedsiębiorczości. Rozwój szkoły jest bezpośrednio uzależniony od jakości zasobów ludzkich. Im większa wiedza i kompetencje, tym większy „niepokój twórczy”, 
im skuteczniejszy sposób wykorzystania potencjalnych możliwości każdego człowieka, tym lepszy rozwój instytucji. Dlatego też proces szkolenia i podnoszenia kwalifikacji zawodowych nauczycieli jest postrzegany przez większość badanych jako istotny czynnik ich efektywnego funkcjonowania w roli zawodowej.

Badania pilotażowe przeprowadzone na przedstawionej próbie badawczej dowodzą, że podnoszenie kwalifikacji jest przez respondentów spostrzegane jako stały element ich życia zawodowego. Nauczyciele są zainteresowani rozwojem zawodowym poprzez różne formy szkoleniowe. Uważają, że dzięki nim stają się efektywnymi profesjonalistami. Identyfikują się z swoją pracą poprzez zrozumienie jej strategii i celów działania. Zaspokajają swoje ambicje, potrzeby samorealizacji i budowania ścieżki rozwoju. Wzbogaca to zasób ich kompetencji, dając możliwość podejmowania coraz trudniejszych wyzwań. Możliwość wzięcia udziału w szkoleniu jest czasem postrzegana jako forma nagrody i wyróżnienia, co w takim przypadku pełni funkcję motywacyjną.

W obecnej rzeczywistości musimy zdawać sobie sprawę z tego, że pozycję rynkową i przyszłość polskiej szkoły trzeba budować na kreatywności ludzi, gdyż w szkołach przyszłości podstawą tworzenia sukcesu będzie wysiłek intelektualny i dojrzała samodzielność twórczo myślących, ciągle doskonalących się i żądnych wiedzy ludzi. Właśnie dlatego tak ważne jest doskonalenie zawodowe nauczycieli.

\section{BIBLIOGRAFIA}

Armstrong, M. (2000). Zarządzanie zasobami ludzkimi. Kraków: Oficyna Ekonomiczna, Dom Wydawniczy ABC.

JANOWSKA, Z. (2001). Zarzadzanie zasobami ludzkimi. Wyzwanie XX wieku. Warszawa: Polskie Wydawnictwo Ekonomiczne.

JAnkowski, D., Przyszczypkowski, K., SkrzypCzak, J. (1996). Podstawy edukacji dorostych. Zarys problematyki. Poznań: Wydawnictwo Naukowe UAM.

GRIFFIN, R.G. (2010). Podstawy zarzadzania organizacjami. Warszawa: Wydawnictwo Naukowe PWN.

Knowles, M.S., Holton, E.F. III, SwAnson, R.A. (2009). Edukacja dorostych. Warszawa: PWN.

KróL, H., LuDWICZYŃSKI, A. (red.) (2007). Zarządzanie zasobami ludzkimi. Tworzenie kapitału ludzkiego organizacji. Warszawa: Wydawnictwo Naukowe PWN.

McKennA, E., BeEch, N. (1999). Zarzadzanie zasobami ludzkimi. Warszawa: Wydawnictwo Gebethner i Spółka.

OsmelaK, J. (1999). Zarzadzanie zasobami ludzkimi. Warszawa: Oficyna Wydawnicza Ośrodku Postępu Organizacyjnego. 
PoczTowski, A. (2008). Zarzadzanie zasobami ludzkimi. Warszawa: Polskie Wydawnictwo Ekonomiczne.

Suchy, S. (2010). Edukacja dorostych pracowników i bezrobotnych. Warszawa: Difin.

SZKuTNICKI, P. (2001). Przekonać załogę do zmian. Personel i zarządzanie, 15/16, 6.

Turos, L. (2004). Andragogika ogólna. Warszawa: Wydawnictwo Akademickie Żak.

Wiatrowski, Z. (2005). Podstawy pedagogiki pracy. Bydgoszcz: Wydawnictwo Akademii Bydgoskiej im. Kazimierza Wielkiego.

\title{
ROZWAŻANIA O ZNACZENIU DOSKONALENIA ZAWODOWEGO NAUCZYCIELI EDUKACJI WCZESNOSZKOLNEJ
}

\begin{abstract}
STRESZCZENIE
Kształcenie ustawiczne nauczycieli, jak sama nazwa wskazuje, oznacza, że proces uczenia się trwa całe życie, od narodzin aż do kresu jego istnienia. Jest to zjawisko dynamiczne, nieprzerwane i konieczne. Istotą kształcenia ustawicznego jest oddziaływanie na rozwój człowieka na każdym etapie jego życia w sposób najbardziej optymalny, umożliwiający mu zajęcie właściwego miejsca w stale zmieniającej się rzeczywistości. Artykuł jest próbą udzielenia odpowiedzi na pytanie, czy podnoszenie kwalifikacji zawodowych przez nauczycieli edukacji wczesnoszkolnej wpływa pozytywnie na ich postawy i tym samym zwiększa ich satysfakcję z pracy, oraz weryfikacją hipotezy, że podnoszenie kwalifikacji zawodowych ma pozytywny wpływ na postawy nauczycieli, przez co wzrasta ich zaangażowanie i satysfakcja z pracy.
\end{abstract}

Słowa kluczowe: kwalifikacje i kompetencje zawodowe nauczycieli; edukacja ustawiczna.

\section{CONSIDERATIONS ABOUT THE MEANING OF PROFESSIONAL DEVELOPMENT FOR PRELIMINARY SCHOOL TEACHERS}

\section{SUMMARY}

The lifelong education of teachers means, as the term implies, that learning is an ongoing process spanning an individual's lifetime. It is a dynamic, uninterrupted and necessary process. Lifelong education seeks to have an impact upon an individual's development at every stage of a lifetime in the most effective manner, enabling a person to respond appropriately to a continuously changing environment. This article attempts to answer the question whether professional development and skills enhancement by preliminary school teachers have a positive effect on their attitudes and thus increase their job satisfaction. It also attempts to verify the hypothesis that professional development and skills enhancement have a positive impact on teachers' attitudes, which increases their engagement and job satisfaction.

Key words: teachers' professional qualifications and competencies; lifelong education. 